\title{
SOME ASPECTS OF BEE POPULATION PRESERVATION
}

\author{
Ilga Krampuza \\ Mg.iur., Mg.soc.sc., lecturer, researcher, Rezekne Academy of Technologies, Rezekne, \\ Latvia, e-mail: ilga.krampuza@rta.lv
}

Received: 5 May 2020 / Revised: 16 June / Accepted: 13 August 2020 /

Published: 30 November 2020

\begin{abstract}
Destructive influence of pesticides on bee population, as well as on people and the environment has been analysed in the research paper. The aim of the paper is to define topical issues, which have to be solved in order to protect bee population and offer the solutions for bee protection against using of chemicals. The issues of bee population protection have been examined in the context of people and environment protection by the assistance of the systematic method. The comparative method serves in order to view the hazard of bee population in different countries. The development of the normative acts, which regulate bee protection from the impact of pesticides has been discussed by the assistance of the historical method. The following hypothesis has been put forward: the protection of bee population is possible via improvement of the normative legal framework, which refers to the usage of pesticides. The novelty of the research is the offer of a normative act amendment, which would provide the checking of pesticide usage in municipalities.
\end{abstract}

Keywords: bees, neonicotinoids, normative acts, pesticides.

JEL code: $K 32$.

\section{Introduction}

The legal framework of bee protection from pesticides, including the usage of neonicotinoids, has been viewed in the research; the problems of both the legal framework shortage and its application have been identified. Destructive influence of pesticides on bee population, as well as on people and the environment has been analysed in the research paper.

The aim of the paper is to define topical issues, which have to be solved in order to protect bee population and offer the solutions for bee protection against using of chemicals.

The issues of bee population protection have been examined in the context of people and environment protection by the assistance of the systematic method. The comparative method serves in order to view the hazard of bee population in different countries. The development of the normative acts, which regulate bee protection from the impact of pesticides has been discussed by the assistance of the historical method.

The following hypothesis has been put forward: the protection of bee population is possible via improvement of the normative legal framework, which refers to the usage of pesticides. 
The novelty of the research is the offer of a normative act amendment, which would provide the checking of pesticide usage in municipalities.

\section{Literature review}

The Food and Agriculture Organisation of the United Nations Organisation (hereinafter in the text - FAO) considers that out of 100 species of cultivated plants, which provide around $90 \%$ of food all over the world, 71 $\%$ are pollinated by bees. Most of the crops grown in the European Union (hereinafter in the text - EU) depend on the insects' pollination. Bees all over the world annually provide the pollination of cultivated plants at a value of 153 billion Euros, in Europe - at a value of approximately 22 billion Euros (European Red List of Bees, 2014). Professional bee -keepers justifiably emphasise the role of the colonies not only in the pollination of cultivated plants but also in the viability maintenance of the whole ecosystem (Latvijas biškopības programma..., 2019). Bees provide the preservation of biological diversity and the pollination of varied crops and wild plants. In addition, bees directly contribute to human welfare via production of honey, pollen, wax, propolis and other food products. It can be concluded that the upkeep of the number of bees at least at the present quantity and the increase of the quantity are essentially important for all the community.

Unfortunately, during the period of the last 10 to 15 years, the number of bees in the countries of Western Europe was decreasing, particularly in France, Belgium, Switzerland, Germany, the United Kingdom of Great Britain and Northern Ireland, the Netherlands, Italy, Spain (Bee health, 2019) and all over the world. A lot of pollinators' species have extinct or are on the brink of extinction (Eiropas Komisija, 2018). The increase of intensive agriculture, which at the moment relates to the usage of pesticides, is recognised as the main reason for the decrease of the number of bees.

The researches done have proved that one of the most broadly used insect destroyers - neonicotinoid - relates to the decrease of the number of bees. It is wide-spread because of its strong impact. Neonicotinoids are pesticides, the basis of which is nicotine. Neonicotinoids affect insects' nervous system and impede the excretion of acetylcholine during the impulses sent by the nerves among the ends of the nerves; as the result, the insect gets paralyzed and dies (Valsts augu aizsardzības dienests, 2012). The following active substances belong to the neonicotinoids: thiamethoxams, thiacloprid, clothianidin, imidacloprid, fipronil, acetamiprid, dinotefuran and nitepyram.

There are agents, which contain thiamethoxams: Cruiser 70 p.s. (has been registered but is not on the market), Actara 25 WG and Cruiser OSR in the Latvia register of plants protection agents (hereinafter in the text - PPA) 
of the State Plant Protection Service (hereinafter in the text - SPPS). One PPA, which contains thiacloprid - Proteus OD (Valsts augu aizsardzības dienests, 2012) - out of other neonicotinoids, has been registered in Latvia. Consequently, the following neonicotinoids are used in Latvia: Actara 25 WG, Cruiser OSR and Proteus OD.

For example, the insecticides Actara $25 \mathrm{WG}$, which contain the active substance thiamethoxams, are used for the spray of plants' leaves and seeding in order to eliminate the pests, which have sucker-type and some have rodent- type mouth organs. The pests, which have to be eliminated, are affected through touch and through the digestive apparatus. The functioning mechanism of Actara 25 WG causes the functioning disturbance of the pests' nervous system receptors (Syngenta.lv, 2019). It is an insecticide of systemic impact for pest elimination in plantings of cucumbers and tomatoes in hothouses, sowings and plantings of decorative plants in hothouses and decorative plants (in pots) in permanent hothouses.

Regulation No. 1907/2006 has to be recognised as a radical turning point in the usage of chemicals, including the limitation basis of neonicotinoid usage in the $\mathrm{EU}$ and the Republic of Latvia (Regula Nr.1907/2006, 2006). A new period started with this normative act, as the working out, production, release into the market and usage of a chemical substance is regulated. The regulation substitutes approximately 40 legal acts, systematising the conditions, which existed before. The regulation particularly marks out the principle of precaution, namely, the producers, importers and users are responsible in order to secure the fact that they produce, release into market or use the substances, which do not make a harmful impact on the environment. The duty to evaluate the possible harm has been redirected from the state agencies to the producers.

In 2009, Regulation No. 1107/2009 was passed (Regula Nr.1107/2009, 2009). It is provided in it that pesticides may be attested at the EU level only in case if their usage do not have an inadmissible influence on bees' health or if it has an insignificant impact on honey bees. The maximum admissible amounts of pesticide remnants are determined in Regulation No. 396/2005 (Regula Nr. 396/2005, 2005). According to the EC 2010 directive $2010 / 21 /$ EU in relation to the particular regulations on neonicotinoids, the risk diminishing requirements for bees are included, labelling requirements have been enforced (Direktīva 2010/21/ES, 2010.), particular measures, which have to be taken into consideration, have been prescribed working with PPA which contain clothianidin, thiamethoxams and imidacloprid.

In 2012 the European Commission (hereinafter in the text - EC) rendered the mandate to the European Food Safety Authority (hereinafter in the text - EFSA) to do the evaluation of information on the active substances of the neonicotinoids group's impact on bees. 
On January 16th, 2012 EFSA published the conclusions, where a high risk for bees was found in the result of PPA usage (European Food Safety Authority, 2020c). Based on the research results, the EC concluded that the usage prescriptions for the active substances clothianidin, thiamethoxams and imidacloprid do not correspond to the requirements of the Regulation $1107 / 2009 / E C$, article 4. (Regula Nr. 1107/2009, 2009) It was obvious in the conclusion of EFSA that while using the chemicals mentioned above, a high risk to influence bees' population in a negative way cannot be excluded. The EC justifiably decided that the list of the allowed powerful chemical substances has to be changed and that is why Regulation No. 540/2011/EC has to be amended.

Since 2013, the enforcement of the EFSA bee guidelines has been discussed (European Food Safety Authority, 2013a). This document is recognised as the scientific standard of pesticide prevention. The bee guidelines are recognised as a proof that chemical usage have to be forbidden or at least their usage has to be decreased in intensive agriculture in order to protect bees from extinction. The guidelines have been used in order to prove the harm of neonicotinoids for bees. The agreement that the European Chemicals Agency (hereinafter in the text - ECHA) and EFSA will collaborate in order to harmonize opinions on the evaluation of pesticide risks for bees, it has to be recognised as an essential step.

In general, the authoritative organisations have established that, unfortunately, pesticides, which have originally been used in agriculture, have also been found in food (Medina-Pastor, Triacchin, 2020), therefore every food user sequentially use them in "the food chain." But the producers and users of the chemicals immediately tried to object that the application of the EFSA guidelines would significantly decrease the range of the pesticides, which have been allowed in Europe (Neimane, 2019); it, in turn, would decrease the amount of agricultural products produced.

In 2016 EPSA warned that bees can contact neonicotinoids also outside the cultivated fields because these insecticides in nature spread rapidly and pollute wild flowers. The research in Germany proved a rapid decrease of the number of insects, for example, during the period of 27 years the biomass of insects has decreased by $75 \%$. The decrease is explained by intensification of agriculture, including the usage of pesticides. Therefore, more than 80 nongovernmental organizations all over the world have united in the coalition Save the Bees (Save The Bees Coalition, 2017) with the aim to achieve an EU decision to immediately and completely forbid the usage of neonicotinoids.

Article 191 of the Treaty on the Functioning of the European Union (Eiropas Savienības oficiālais vēstnesis, 2012), which stipulates that the policy of the Union in regard to the environment assists to achieve the aim to preserve, protect and improve the quality of the environment; protect 
people's health. The principle of precaution and preventive activity determines that the damage done to the environment has to be repaired, firstly averting its cause and that the polluter pays.

The duty of every national country is envisaged in the Directive 2009/128/EC (Direktiva 2009/128/EK, 2009). It is determined in the Directive that every member state has to pass a national action plan setting quantitative targets, tasks, activities and a performance schedule in order to reduce the risk caused by pesticide usage and influence on human health and the environment. Spraying of pesticides from air on cultivated plants is banned.

In 2013 the EC decided to ban usage of neonicotinoids for the plants, which attract bees, after 19 year-long efforts of bee-keepers and environment activists. At the same time the EC summoned the producers of pesticides Bayuer and Syngenta to engage into preservation of wildlife and provide additional data in order to evaluate better the toxicity of the chemicals used. Later, in February of 2018, EFSA published a new estimate, which plainly testified that these pesticides endanger both wild and honey bees (Potts, 2018).

It has to be recognised that the EU has introduced a range of activities, which plays into pollinators' hands, particularly the activities in the framework of environmental and health policies (Direktiva 79/409/EEK, 1979), as well as in the framework of the Common Agriculture Policy, cohesion policy and innovation policy. Several national and regional strategies on the issue of pollinators have been introduced. The fact that a unified, consensual action of the EU level for extinction elimination of pollinators with a common vision, which would include different spheres and policy branches is recognised to be a problem. The strategic aims and a range of actions, which the EU and its member states have to do to prevent the extinction of the pollinators in the EU in order to stop the extinction of biological diversity and ecosystem services and to renew them, have been worked out. The EU pollinator initiative has powerful support of the people groups conserned, particularly of a broad community (Eiropas Komisija, 2018). The implementation of the good intentions mentioned at the moment to the great extent lies with every country.

A broad evaluation of honey, bee bread, pollen was done in Latvia in the period of $2014-2016.382$ bee products were analysed during these years, and some of pesticides were found in 47 samples of them (Grinvalde, 2017). Therefore, it is proved that the chemical used in Latvia leaves consequences even in the final product. Unfortunately, there is no information on the amount of PPA used at the SPPS's disposal. But the positive fact is that PPA submitters have to hand in the research works on the impact of a particular PPA on bees and other arthropods before PPA registration. 
In February 2018, EFSA published a new evaluation of neonicotinoids, which plainly approved that these pesticides endanger both wild and honey bees (Potts, 2018). The EU countries' agreement of April 27th, 2018, which fully banned three plant processing chemical agents of neonicotinoids' group: imidacloprid, clothianidin and thiamethoxams from being used outdoors, did not solve all the issues, but it is evaluated as an essential step. These agents are allowed to be used only in greenhouses.

However, it was revealed immediately struggle with the lobby of chemical users is very difficult. Authoritative researchers have recognised that the ban of neonicotinoids itself will not solve the problem (Buike, 2018). Really, after the ban of neonicotinoids the farmers choose other agents. The next generation of pesticides is already prepared. Besides, it has to be recognised that the new class of pesticides, which has come instead of neonicotinoids, could be equally dangerous to the bees, which pollinate cultivated plants, as the neonicotinoids mentioned. New insecticides are based on the ground of sulfoximine and leave a negative impact on both the reproductive abilities of bees and on the growing pace of bee colonies (Šveicars, 2018). It is clear that also other pesticides, which are equally harmful, will follow. Therefore, this vicious circle has to be torn. Otherwise, there are no hopes that a significant step will be made in environmental protection (Buike, 2018). Therefore, we must not put up only with the ban of neonicotinoids, the ban of all pesticides has to be achieved.

The ban of pesticides has a twofold resistance: 1) the lobby of chemical producers, 2) the lobby of conventional agriculture. For example, responding to the resolution passed in April 2018 in Brussels, the association Farmers Parliament has announced that the ban of these insecticides will leave a negative impact on the national economy, because the producers will have to compete with the farmers from the developing countries, where the agents containing these preparations are permitted and therefore the costs of their products are lower (Zariňš, 2018). The owners of large land areas have mentioned that the ban or limitation of pesticides can reduce the crop. However, the previous researches, which have been done in America, France and Italy, on the contrary, have proved that the reduction of pesticides has not considerably decreased the crops (Gulbinska, 2017).

There is a reason to consider that the producers of neonicotinoids Bayer and Syngenta avoid providing the new data in order to evaluate accurately the toxicity of these substances.

In general, the EU has introduced a range of activities, which play into pollinators' hands, particularly the activities in the framework of environmental and health policies, (Direktiva 79/409/EEK, 1979) as well as in the framework of the Common Agriculture Policy, cohesion policy and research and innovation policy. Several national and regional strategies on 
the pollinators' issue have also been introduced. A unified, consensual action of the EU level has not been implemented untill the present for the prevention of pollinator extinction with an integrated approach, which would focus on different fields and policy branches. It is clear that the EU and its member states have to solve this problem together. The strategic aims and a range of activities, which must be implemented by the member states, have been worked out.

It has to be agreed with EFSA and the French Agency for Food, Environment and Occupational Health Safety (ANSES) that the activities of the broadest scope have to be worked out and implemented, which really would reduce the risk for bees (European Food Safety Authority, 2013a, $2013 \mathrm{~b}$ ). In addition, it has been proved that bees can ingest the remains of various pesticides from nectar, pollen and water. Therefore, sufficient protection activities are necessary for the protection of bee product acquisition places from chemicals. Conferences take place all over the world where the provision of bees' health is discussed. For example, on December 9th, 2019 a conference took place in Paris (International ANSES-EFSA Scientific Conference Day Organised by: ANSES - EFSA, 2019), where the ways were looked for sustainable bee-keeping development. It has been found out that the member states cannot reach an agreement that the EU will check the damage of chemicals on bees during a sustainable period, including the harm done to bee larvae.

More than 240000 Europeans signed a petition, which demanded the standard protection of bee gold against noxious pesticides. One of the main causes is industrial agriculture, which results in "exhausted" landscapes, creates the conditions that the bees do not have sufficient sources of nutrition and subjects them to pesticides (SumOfUs, 2019).

At present, the requirement for a farmer to master knowledge has been consolidated in Latvia's normative acts if the farmer uses chemicals on his/her farm. Since 2013, also a tractor- driver who is directly exposed to dust has to acquire knowledge. It is essential, as wrong dust can cause the usage of excessive chemical dosages, the dust of the field located nearby, the dust in an inappropriate time, chemicals can get into water.

According to SPPS information, for example, in 2016 the service has received 29 justified complaints on illegitimate usage of fertilization agents, 64 ones - on the usage of plant protection agents; in 2017 - 52 ones, during seven months of 2018 - 46 (Pohodneva, 2018). Consequently, the illegitimate usage of pesticides increases.

The Plant Protection Law (Augu aizsardzības likums, 1998) determines the basic competence of the usage regulation, the institutions in charge, but Cabinet regulation No. 950 "The usage regulation of plant protection agents", article 20, determines that if a person uses an agent of plant protection, the 
labelling of which has an instruction: "Toxic for bees" or an effects characteristics R57 of the chemical agent; it means that three days before the processing of sowings or plantings, the legal possessors of bee colonies, whose apiaries (or hives) are located within the radius of two kilometres from the place processed and whose bee colonies have been registered in accordance with the normative acts on the registering of animals, herds and accommodations and animal labelling according to the procedure laid down (Augu aizsardzības līdzekḷu, 2011).

Article 102.2 of the Latvian Administrative Violations Code (hereinafter in the text - LCAO) (Latvijas Administratīvo pārkāpumu kodekss, 1985) on the violation of the requirements for the import, distribution, storage and use of plant protection products provides an administrative punishment, moreover, the offender has to cover the losses caused. However, it is not always possible to prove that the usage of particular pesticides has caused the extinction of bees. Furthermore, in order to provide the proofs for legal proceedings, a bee- keeper has to gather the range of proofs, which is not easy and cheap at all.

There are also positive examples. It has been found out in the case of administrative offence that a person had treated the fields of rapeseed by chemicals. The court has justifiably acknowledged that the user of chemicals broke the regulations, which were in force at the time, which envisaged the duty of the pesticide user to warn the legal possessors of bee colonies whose apiaries (or hives) are located within the radius of two kilometres from the place processed and whose bee colonies have been registered in accordance with the normative acts on the registering of animals, herds and accommodations and animal labelling according to the procedure laid down. (Spriedums 2013.gada 17. jūnijs, lieta Nr.142273711, 2013)

If the normative acts being in force are interpreted only literally, the user of chemicals has rights to spray the fields even in front of someone's house. Of course, it can be hoped that the bees could be preserved on the account of neighbours' good relations, namely, the pesticide user guided by a good will warn the owners of the apiaries on the actions planned. It is unlikely and this gap in the normative regulation cannot be allowed. That is why the user of pesticides has to be applied a duty to inform the owners of apiaries on the planned usage of chemicals, but it also has to be envisaged that the municipalities have to control the accomplishment of this duty. This solution is based on the consideration that 1) all information on the land owner is at local municipalities' disposal, 2) in collaboration with the Rural Support Service and other national institutions, municipalities have information on the local farmers, bee apiaries and 3) municipalities have the resources of the rural municipalities' staff and also technical resources. Therefore, in article 15 of the law "On municipalities", it is necessary to 
envisage the duty for municipalities to ensure the rule of law of all kinds at their administrative territories.

Practice proves the necessity of municipality involvement in the legal handling of pesticides. In Zemgale, "Lauku agro" Ltd ("Countryside Agro") belonging to the citizen of Denmark sprayed the fields of rapeseed during the day and 100 bee colonies died (Miglošanas dēl masveidā iet bojā bites, 2010) .Later, the manager of the Ltd explained that the bee-keepers had not been honest because they did not inform the administration of the rural municipality where the apiaries were located; he had only tried to survive. It is evident that protection of bee population from the users of pesticides have to be stipulated not only formally in the normative acts (The usage terms are already envisaged in law), but the mechanism how the usage of these regulations has to be implemented has to be envisaged. The local authorities having both information and other necessary resources can do it in the best way. If the specification of competencies with the SPPS is necessary for specification of the action, it has to be done via the Cabinet of Ministers' assistance, which would be based on law amendments.

In addition, everyone has an opportunity to involve into European citizens' initiative "Save the bees! The protection of biological diversity and improvement of insects' habitat in Europe". The initiative appeal is "to pass the legal acts in order to preserve and improve the insects' habitat as the indicators of an undamaged environment". If it becomes real to gather at least one million of supporters from seven various countries, the EC will have to respond during three months. The aims of this initiative is the development of biological diversity as the basic aim of agricultural activity; sharp reduction of pesticides usage, increase of research, supervision, improvement of education (Latvijas sabiedriskie mediji, 2019). It is necessary to implement a range of activities, which include the implementation of informative activities, involvement of as a broad community as possible in search of solutions (public organisations, discussions, other forms) for preservation of biological diversity and the implementation of multistep risk evaluation activities.

\section{Research results and discussion}

It has been found out as the result of the research that the pesticides, particularly the ones containing neonicotinoids affect the nervous system of bees and, as the result, cause their extinction. The next generation chemicals have already been worked out and are being used, and it influences bees aggressively. The presence of pesticides has also been found in the final products, consequently, they influence bees, people and also the environment. The limitation of pesticide production and usage is linked with 
the discussions and the passing of regulations and directives during a longer period of time in the European Union. It has to be recognised that during the passing process of these normative acts, a huge resistance of pesticide producers and farmers as the users has to be met, taking into consideration that considerable financial resources are also at their disposal. The proofs have to be looked for that the reduction of chemical usage will not leave any impact on the amounts of the final product. Bee-keepers' initiatives, which have resulted in research works, on which to base the struggle against the usage of pesticides, play a considerable role in the development of normative regulation. Simultaneously, the initiative of the national countries has a significant role. In Latvia, a judicial basis for the protection of bee population, which is based on the Treaty on the Functioning of the European Union, the regulations, the Plant Protection Law, and the regulations of the Cabinet of Ministers on pesticide usage, has already partly been developed. The supervision of pesticide usage has to be recognised as the weak stage. Therefore, it is necessary to improve the control of pesticide usage, using the capacity of municipalities, the importance of municipalities has to be increased.

\section{Conclusions and suggestions}

1. The pesticides, which are used in intensive, industrial agriculture, directly influence bee population, causing their extinction and reduce the diversity of the biological environment, but subordinately influence people in a negative way via pesticide remains found in the final products.

2. The ban of pesticides has a twofold resistance: the producers of pesticides and those who practice intensive agriculture.

3. The activities of the broadest nature in order to achieve the reduction and the ban of pesticides have to be implemented both in the European Union and Latvia. The pesticides containing neonicotinoids, which, according to the scientific research, cause the extinction of the bees, are still in the Register of the State Plant Protection Service.

4. It is necessary to supplement the first part of article 15 of the Law "On municipalities" with paragraph 24 and envisage that municipalities have a duty to provide the rule of law within the borders of their administrative territory, but the duties, which relate to the handling of pesticides, have to be left in the competence of the Plant Protection Service.

5. In order to preserve the population of bees, it is necessary to implement a range of activities, which involve the implementation of informative activities, to involve as a broad community as possible in the search of solutions (public organizations, discussions, other forms); improvement 
of normative acts in order to preserve biological diversity, implementation of multistage risk prevention activities.

\section{References}

1. Augu aizsardzības līdzekḷu lietošanas noteikumi (2011). Ministru kabineta noteikumi Nr.950. Pieejams: https://likumi.lv/ta/id/241853-augu-aizsardzibas-lidzeklulietosanas-noteikumi

2. Augu aizsardzības likums (1998). Latvijas Vēstnesis, (Nr.388/399). 30.12.1998.

3. Bee health (2019).Retrieved from http://www.efsa.europa.eu/en/topics/topic/beehealth

4. Buike, I. (2018). Neonikotinoīdi aizliegti - vai ar bitēm būs viss kārtībā? Rerieved from https://ir.lv/2018/05/02/neonikotinoidi-aizliegti-vai-ar-bitem-bus-viss-kartiba/

5. Direktiva 2010/21/ES (2010). Retrieved from https://eur-lex.europa.eu/legalcontent/LV/TXT/?uri=CELEX\%3A32010L0021

6. Direktiva 79/409/EEK (1979). Retrieved from https://eurlex.europa.eu/eli/dir/1979/409/oj/?locale=LV

7. Direktīva 2009/128/EK (2009). Retrieved from https://eur-lex.europa.eu/legalcontent/lv/TXT/?uri=CELEX\%3A32009L0128

8. Eiropas Komisija (2018). Komisijas Pazinojums Eiropas Parlamentam, Padomei, Eiropas Ekonomikas un Sociālo Lietu Komitejai un Reǵionu Komitejai, ES Apputeksnētāju iniciatīva, Retrieved from https://op.europa.eu/en/publicationdetail/-/publication/e038c9ea-657f-11e8-ab9c-01aa75ed71a1/language$\underline{\mathrm{lv} / \text { format-PDF }}$

9. Eiropas SAvienības oficiālais vēstnesis (2012). Lìgums par Eiropas Savienības darbību. Retrieved from https://eur-lex.europa.eu/resource.html?uri=cellar:88f94461-564b4b75-aef7-c957de8e339d.0015.01/DOC 3\&format=PDF

10. European Food Safety Authority (2013a). EFSA Guidance Document on the risk assessment of plant protection products on bees (Apis mellifera, Bombus spp. and solitary bees. Retrieved from https://efsa.onlinelibrary.wiley.com/doi/epdf/10.2903/j.efsa.2013.329512.

11. European Food Safety Authority (2013b). Outline of the revision of the Guidance on the risk assessment of plant protection products on bees (Apis mellifera, Bombus spp. and solitary bees). Retrieved from http://www.efsa.europa.eu/sites/default/files/event/Bee Guidance review.pdf

12. European Food Safety Authority (2020c). Bees and pesticides: third consultation on guidance review. Retrieved from http://www.efsa.europa.eu/en/news/bees-andpesticides-third-consultation-guidance-review

13. European Red List of Bees (2014). Luxembourg: Publications Office of the European Union, 2014.

14. Grīnvalde, Ž. (2017). Vai Latvijas medū ir pesticīdi? Grēko bišu maizes ražotāji. Retrieved from https://laukos.la.lv/vai-latvijas-medu-ir-pesticidi

15. Gulbinska, P. (2017). Kaitīgais nezālu apkarotājs glifosāts: Nav pārspīlèti teikt, ka tas ir visur. Retrieved from https://lr1.lsm.lv/lv/raksts/zinamais-nezinamaja/kaitigaisnezalu-apkarotajs-glifosats-nav-parspileti-teikt-ka-ta.a82413/

16. International ANSES-EFSA Scientific Conference Day Organised by: ANSES - EFSA (2019). Retrieved from https://www.anses.fr/en/content/international-anses-efsascientific-conference-day 
17. Latvijas Administratīvo pārkāpumu kodekss (1985). Latvijas Padomju Sociālistiskās Republikas Augstākās Padomes un Valdības Ziṇotājs (Nr. 51). 20.12.1984.

18. Latvijas biškopības programma 2020-2022. gadam (2019). Retrieved form http://www.lad.gov.lv/files/ladDocument/1832/LV biskopibas programma 20202022.pdf

19. Latvijas sabiedriskie mediji (2019). Savācot miljonu parakstu par bišu glābšanu, pilsoṇi varēs prasit EK reakciju. Retrieved from https://www.lsm.lv/raksts/zinas/latvija/savacot-miljonuparakstu-par-bisu-glabsanu-pilsoni-vares-prasit-ek-reakciju.a319104/

20. Medina-Pastor, P., Triacchin, G. (2018). The 2018 European Union report on pesticide residues in food. Retrieved from https://efsa.onlinelibrary.wiley.com/doi/10.2903/j.efsa.2020.6057

21. Miglošanas dēl masveidā iet bojā bites (2010). Retrieved from: htpp:// https://jauns.lv/raksts/zinas/214648-miglosanas-del-masveida-iet-boja-bites.

22. Neimane, Z. (2019). Vai Eiropā notiek pesticīdu uzvaras gājiens pār bišu aizsardzību? Retrieved from https://www.lsm.lv/raksts/dzive--stils/vide-un-dzivnieki/vaieiropa-notiek-pesticidu-uzvaras-gajiens-par -bisu-aizsardzibu.a310350

23. Pohodṇeva, M. (2018). Miglo un smidzina? Sūdzību izmeklēšanas anatomija Augu aizsardzības dienestā. Retrieved from https://laukos.la.lv/sudzibu-izmeklesanasanatomija

24. Potts, S. (2016). The Assessment Report to the Intergovernment Science-Policy Platform on Biodiversitu and Ecosystem Services on Pollinators and Food Production, Secretariat of the Intergovernmental Science-Policy Platform on Biodiversity and Ecosystem Services, Bonna: Vācija.

25. Regula Nr. 1107/2009 (2009). Retrieved from https://eurlex.europa.eu/eli/reg/2009/1107/oj/?locale=LV

26. Regula Nr. 1907/2006 (2006). Retrieved from https://eur-lex.europa.eu/legalcontent/lv/TXT/?uri=CELEX\%3A02006R1907-20140410

27. Regula Nr.396/2005 (2005). Retrieved from $\underline{\text { https://eur- }}$ lex.europa.eu/eli/reg/2005/396/oj/?locale=LV

28. Save Teh Bees Coalition (2017). Retrieved fromhttps://beecoalition.eu/

29. Spriedums 2013.gada 17.jūnijs lieta Nr.142273711 (2013). Retrieved from https://www.tiesas.lv/Media/Default/Admin.tiesu\%20spriedumi/Admin.apg.tiesas \%20spriedumi/J\%C5\%ABnijs/17.06.2013/AL 1706 apg_AA43-1568-13 18.pdf

30. SumOfUs (2019). Majority of MEPs Throw Out Weak Plans to Protect Bees after 240,000 People Join Public Campaign Demanding Better. Retrieved from: https://www.sumofus.org/media/majority-of-meps-throw-out-weak-plans-toprotect-bees-after-240000-people-join-public-campaign-demanding-better/

31. Šveicars, R. (2018). Pētījums: Arī jaunie pesticīdi apdraud bišu veselību. Retrieved from https://laukos.la.lv/petijums-ari-jaunie-pesticidi-apdraud-bites

32. Syngenta.lv (2020). Actara $25 \quad W G . \quad$ Retrieved from https://www.syngenta.lv/product/crop-protection/insekticids/actara-25-wg

33. Valsts augu aizsardzības dienests (2012). Atbilde. Retrieved from http://www.vaad.gov.lv/32/section.aspx/1906

34. Zarin̦š, J. (2018). ES vienojas aizliegt bitēm kaitīgā pesticīda - neonikotinoīda lietošanu. Retrieved from https://skaties.lv/zinas/latvija/es-vienojas-aizliegt-bitemkaitiga-pesticida-neonikotinoida-lietosanu/ 